\title{
A Report of the interdisciplinary education approach within the universidad de La Frontera Dental Curriculum
}

\author{
Un Reporte del Enfoque de Educación Interdisciplinaria en el Plan de \\ Estudios de la Carrera de Odontología de la Universidad de La Frontera
}

Yanela Aravena Rivas"; Marcela Huanquilef Arriagada²; Manuel Arellano Villalón²; Javiera Nuñez Contreras ${ }^{3}$ \& Ramón Fuentes Fernández ${ }^{2}$

ARAVENA, R. Y.; HUANQUILEF, A. M.; ARELLANO, V. M.; NUÑEZ, C. J. \& FUENTES, F. R. A report of the interdisciplinary education approach within the universidad de La Frontera Dental Curriculum. Int. J. Odontostomat., 15(1):300-305, 2021.

ABSTRACT: Interprofessional education has become widely recognised as fundamental to educate new generations of dentists able to successfully join the dental public and private sectors and provide appropriate dental treatment to complex patients in a complex health system. This article presents the innovated curriculum of the dentistry course at Universidad de La Frontera describing its interprofessional education components. The description of IPE in the dental curriculum was done using Institutional documents. The university vocational training policy provides the framework in which IPE is implemented in undergraduate courses. Six out of eight dental curriculum components included IPE in their educational methodologies: 'Integrated units', 'Culture, society and mankind', 'Prevention', 'Professional Projections', 'Integrated clinics', and 'Professional Practice'. IPE is present thorough the dental course from first to final year and it takes different forms within each component. IPE is one of the methodologies used to achieve the learning outcomes stated in the curriculum. Passing through all modules of the dental curriculum leads to the development of generic and professional skills that allow students to obtain their professional title.

KEY WORDS: Dental education, Interprofessional relations, Professional education, Dental Schools.

\section{INTRODUCTION}

Interprofessional collaborative practice (IPC) has been considered as essential to tackle increasingly complex health conditions, improve population health outcomes, reduce healthcare costs and address global workforce challenges (Institute of Medicine, 2003; World Health Organization, 2010). The aging population and the increase of individuals with chronic diseases have intensified the need for interdisciplinary health teams to provide comprehensive health care (Mendis, 2014). The dental profession is no stranger to this paradigm as dental practitioners are required to interact with other medical and dental specialities and social care professionals to provide holistic patientcentred oral health care. To achieve this competency among dental students, interprofessional education
(IPE) has become increasingly prominent in dental school's curriculums in several countries (Davis et al., 2018; Coleman et al., 2018).

An educational model that places IPE as central in its curriculum is capable of meeting the needs of the current health care system in several ways. These include delivery of patient-centred care, provide efficient treatment by reducing gaps and errors that might arise from a traditional individualistic dental practice, encouragement of cultural sensitivity and impact of health inequalities, and improved communication skills with team members, patients, and their families (Ramaswamy et al., 2018). International bodies such as the World Health Organization (World Health

\footnotetext{
${ }^{1}$ Centro de Investigación en Epidemiología, Economía y Salud Pública Oral (CIEESPO), Facultad de Odontología, Universidad de La Frontera, Temuco, Chile.

${ }^{2}$ Departamento de Odontología Integral Adultos, Facultad de Odontología, Universidad de La Frontera, Chile.

${ }^{3}$ Escuela de Odontología, Facultad de Odontología, Universidad de La Frontera, Chile.
} 
Organization), the UK General Dental Council (Wenger, 1998), and the Centre for the Advancement of Interprofessional Education (Centre for the Advancement of Interprofessional Education, 2017) have stated the importance of IPE. However, its implementation in dental education varies between institutions worldwide. For example, in the US, even when an increase in IPE experiences has been reported in the past years (Palatta et al., 2015), most universities did not have a clearly defined IPE model (Ramaswamy et al.).

In Chile, no national guidelines exist regarding IPE for universities teaching health care courses. However, this domain and the competencies associated with it are of great importance for the dental curriculum. The Chilean primary health care system has a family-based model. Families are linked to a specific health team that promotes health, prevents diseases, and provides medical treatment. Dentists must insert on these health teams, not just for the delivery of clinical dental treatment but as a member participating in meetings to discuss promotion, prevention, and integral health treatments (Subsecretaria de Redes Asistenciales, 2013). Meanwhile, in secondary and tertiary health care facilities, dental specialties need to collaborate to deliver complex dental treatments as well as constantly interact with other health professionals in the fields of medicine and nursing when treating patients with complex health conditions.

The dental education programme of the Universidad de La Frontera (UFRO) was created with the intention to tackle the challenges of dental education (Fuentes et al., 1996) such as the predominance of an individualistic clinical focus and the mismatch between dental education, internship programmes and the oral health needs of the local community. In this sense, the core of the undergraduate dentistry course is based on a strong student-centred education in public health, family health, public policies, health administration, health promotion, and leadership. IPE plays an important role from early on in the six-year curriculum. From the first to the fifth year, students develop a solid scientific, ethic, and clinical formation within the university campus, while in their sixth year they do an internship programme in primary public health care services to consolidate the professional skills acquired through their studies. The purpose of this article is to present the innovated curriculum of the dental programme at Universidad de La Frontera identifying the moments where interprofessional education competency is present. Institutional documents were used to describe the dental curriculum and correspond to the following official reports: 'University of La Frontera institutional policy of vocational training' (Universidad de La Frontera, 2007); 'Generic competencies dictionary' (Universidad de La Frontera, 2018); 'Selfassessment report of the dental course for Accreditation purposes' (Universidad de La Frontera, 2017); and 'Dental Faculty Dean management report 2018-2019' (Universidad de La Frontera, 2019).

\section{Curriculum}

Curriculum underpinning: University of La Frontera guidelines. The University of La Frontera is located in the south of Chile. The region is characterised by a high level of poverty, a high proportion of rural population, and the strong presence of indigenous communities (Instituto Nacional de Estadística, 2017). The local context has had a strong influence on the University mission and its vocational training policy. This policy addresses the institutional commitment to excellence, quality education, and social responsibility. Among its core components, it is included a studentcentred education, articulation between courses and grades, outcome-based curriculum design and to improve employment opportunities. The university vocational training policy provides a framework for all undergraduate courses. Establishes that all courses must support the development of professional skills, generic competencies, disciplinary education, curriculum and teacher evaluation, flexibility, academic development, and student exchange programmes. This policy gives importance to holistic, interdisciplinary professional education through the development of generic skills. As the dentistry course is underpinned by this policy, it allowed creating a dental curriculum where IPE can be found thorough its components.

Undergraduate Dentistry Course. The dentistry course was created in 1992 with an innovated teaching methodology based on the SPICES model (Acronym for Student-centred learning, Problem-based learning, Interprofessional teaching, Community- based education, Elective studies, and Systematic approach) (Fuentes et al.). The course graduation profile states that the graduated dentist is a dental professional with a solid scientific foundation and appropriate ethical and humanistic formation, that it is able to participate and lead health teams and who can do clinical dental treatments, promotion, and prevention activities to tackle oral health needs of individuals and communities. Also, the graduated dentist should strive for continuous self-learning in all their actions, and to understand 
human and social behaviours to balance the technical aspects of the profession with psychosocial aspects within an ethical framework. To achieve said profile, the dental course differentiating value is its commitment to linking the students with the regional and national context permanently. Students interact with the local community from the early stages in the course to develop a commitment to their oral health needs and context. The dental curriculum has 8 curricular components distributed across twelve semesters. The curricular components are indicated in Table I. IPE has been identified in six of these curricular components. After completing the tenth semester, students obtain the degree of Bachelor in Dentistry with a mention in prevention, and after completing the internship programme in the twelfth semester they obtain the Dental Surgeon professional title.

A) Curriculum Component: Integrated Units. The Integrated Units are six modules implemented from the first to the sixth semester of the dentistry course. The modules use a problem-based learning methodology where small groups (8-10 students) achieve their learning outcomes by working collaboratively to solve a theoretical case guided by a tutor. The cases are set in a community context and lead students to delve into clinical, social, and psychological areas as well as basic sciences and public health knowledge. The modules encourage leadership and teamwork competencies. Tutors come from a wide array of disciplinary backgrounds different from dentistry so students can learn from their point of view and understand the role of other health professionals in addressing oral health care needs from a biopsychosocial perspective and under the health care system's family-based model.

B) Curriculum Component: Culture, society, and mankind. This component is comprised of eight modules including anthropology, sociology, psychology, and ethics. The second semester, the sociology module, in partnership with the public health module, leads an activity where students must do a community diagnosis in urban and rural areas surrounding the city. The community diagnosis must consider aspects relevant to both sociological and public health perspectives. Among the tasks, students must perform interviews with health workers (nurses, dentists, etc.), interviews with individuals from the local community, a basic oral hygiene examination in a school setting, and implementation of an education programme that considers the results from the community diagnosis. This is the first approach to what students will do in their internship programme at the end of the course. It is an opportunity for them to have their first dentistry-related experience outside the university campus and to observe the challenges associated with social inequalities and the burden of oral diseases.

C) Curriculum Component: Prevention (Public Health). Six public health modules across the first six semesters are part of this curricular component. Apart from the joint activity with the sociology module, IPE is also addressed in other semesters within this curriculum component. In the fifth and sixth semesters, students join a dental team in a primary health care setting for three one-day sessions. In this time, students must do an oral health assessment and basic dental treatment for children. The first session is for performing a dental diagnosis and a treatment plan, while the second and third sessions are aimed to do basic clinical treatment and dental education based on the children's social and family context. In this activity, students must interact with a tutor dentist, the members of the dental team, and other professionals working at the health care centre.

\section{D) Curriculum Component: Professional} Projections. Three modules are part of this curriculum component: family health (eighth semester), planning and administration (ninth semester), and public policies (tenth semester). All these modules are taught by dentists working in the Chilean public health system in service planning, as local health authorities, and as leaders of dental teams at primary health care centres. Their aim is to provide the students with knowledge and a greater understanding of the public health system regarding its legislation, planning, and administration to promote an adequate integration to dental teams when they do their internship programme.

Table I. Distribution of curricular components across semesters of the undergraduate dentistry course.

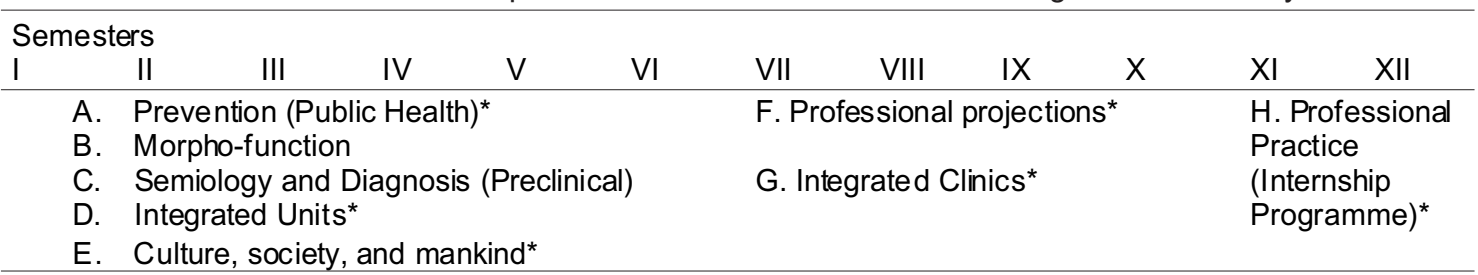

${ }^{*}$ Components in which interprofessional education is implemented. 
E) Curriculum Component: Integrated Clinics. From the seventh to the tenth semester, the integrated clinics curricular component takes most of the teaching schedule. Two paediatric and two adult integrated clinical yearly modules comprise this section of the dental course. The modules are held within the dental school clinic. This integrated approach aims to teach all clinical skills a dentist must know to work in the health system. Undergraduate students must cover all patient's oral health needs including dental education, preventive clinical measures, and dental treatment according to their level of expertise supervised by a tutor, and to refer and work collaboratively with specialists to achieve success in dental treatments. Here, undergraduate students interact with speciality students and dental school teachers. IPE is present when students must seek guidance from professors of different dentistry specialties (endodontics, periodontics, maxillofacial surgery, prosthodontics, radiography, and restorative dentistry) to provide a holistic oral health care treatment plan to their patients. Also, when referring patients for specific complex treatments to students of specialties within the clinic as part of their treatment plan.

F) Curriculum Component: Professional Practice (Internship Programme). The last two semesters of the dentistry course are an internship programme comprised of two modules. The main objective is for students to immerse in the public primary health care system and apply their skills in clinical dental procedures and prevention and promotion of oral health. Students join a dental service for 16 weeks and work in the same national dental programmes implemented in primary services. Students must do dental urgencies and provide dental care to nationally prioritised groups such as children, pregnant women, and older adults. They are under the supervision of a 'preceptor'. Preceptors are dentists working within the service who act as role models for the students and evaluate their daily performance. The university supervises the students with a team of professors who visit each service in a schedule during the academic year. Students must also do promotion and prevention activities in the communities where the services are located. These activities arise from local initiatives, national programmes, and the dental course learning outcomes. The first module requires the students to spend $50 \%$ of their time in these activities and the second a $33 \%$ while the rest is for clinical treatment. During the internship, students must do a 'School monitor training' promotion programme created by the dental school. A school is selected in each local area and dental students must teach a selected group of children about dental health so the children become monitors and role models to their peers. The Faculty of dentistry has legallybinding bilateral agreements with several health services and municipalities in the region to ensure the internship programme has enough spaces for all students and is both beneficial for the student learning process, the health care services, and the local communities. To strengthen the relationship between stakeholders, the university lends dental chairs to primary health care services. This way, dental students increase the service capacity to deliver dental treatments to their communities.

The students are expected to develop two generic competencies: teamwork and complex thinking (Table II). Students hone their teamwork competencies when they join the local primary dental care team and local primary care family team. They have to work collaboratively to provide culturally appropriate dental education and dental care treatment. The health services associated with the internship programme come from different parts of the health system and include rural health care services, urban primary health care centres, intercultural health centres, community hospitals, and tertiary care hospitals. At the end of their internship

Table II. Generic and professional skills stated in the dental curriculum of Universidad de La Frontera, Chile.
A. Generic skills
1. Verbal and Written Communication in Spanish
2. Learn-to-learn
3. Complex thinking
4. Leadership
5. Teamwork
6. Social responsibility
B. Professional skills

1. Identify ecological, biological, and psychosocial phenomena that influence general and oral health.

2. Develop necessary ethical and human values for professional practice, interaction with other people, and performance in the community.

3. Identify oral health needs and understand its significance in the individ ual's general health.

4. Apply oral health preventive measures in individuals and communities.

5. Apply curative techniques usually used in professional practice.

6. Understand administration concepts applied to dental professional practice. 
programme students have worked in two different types of health care services for an extended period. The different types of services lead to a wider set of IPE experiences for the students which is beneficial in their learning process. At the same time, to ensure a minimum development of such competency, the internship programme is established so all students join dental teams and work collaboratively with dentists, assistants, dental nurses, specialists, fellow interns and also with social care professionals and school teachers when performing the community needs assessment and promotion and prevention activities.

One particular subtype of internship programme with strong IPE available is PIRI (Spanish acronym for: 'Interdisciplinary Rural Internship Programme') where students move to a student residence located in a rural area (Serra \& Carrasco, 2009). There, they share housing with interns from other health courses including, medicine, nutrition, physical therapy, nursing, obstetrics, speech therapy and medical technology, and in some cases with other social sciences courses such as physical education, social work, and psychology. As part of PIRI, all students must work collaboratively to create interprofessional health promotion and prevention activities that address the needs of the local community together with their disciplinary-specific professional activities. In this sense, dentistry students not only perform clinical work at the rural health service but also participate in other health initiatives lead by interns from different health courses, as well as having the opportunity to lead activities themselves where they can incorporate the multidisciplinary skillset available at the PIRI residence.

\section{DISCUSSION}

The dental course of the University of La Frontera implements IPE across its curriculum in six of its eight curricular components. From the first semester, students have the opportunity to learn from health professionals from different disciplines and to be in contact with local primary health service teams and communities. IPE is intertwined in the dental course and has adopted different expressions according to the modules learning outcomes and their position within the curriculum. IPE has been associated with the development of important skills for dentists in current times. The sooner students engage in IPE activities, the more tools they develop to join health teams successfully. Students have been shown to have gained a deeper understanding of the dentist role and the other health workers (Kersbergen et al., 2020) as well as a deeper understanding of collaboration resulting in better attitudes about interprofessional teamwork (Wang et al., 2019). Interprofessional collaborative practice has become widely applied in both public and private sectors as it allows to deliver more effective dental care and better use of resources (Weintraub et al., 2019). The Chilean public health system relies heavily on interprofessional teams to tackle the population health needs. Most national dental programmes are carried out in primary health services where the family-based model is applied, while many secondary and tertiary health services have several dental specialties working within the same space. In the private sector, there has been an increase in dental clinics with multiple specialities within dentistry and in combination with other health areas. Also, the arrival of new technologies and the increase of patients with chronic complex health conditions require that newly graduated dentists can collaborate with other professionals. Universities must acknowledge this scenario and adapt their curriculum to train future dentists that can effectively work in the health system.

IPE can play an important role in tackling the traditional shortcomings of dental education. For example, clinical reasoning skills that are learned during the dental course are influenced by learning experiences students face during their studies and cultural factors (Nafea \& Dennick, 2018). In this sense, a curriculum with high IPE could lead to dentists with clinical reasoning that will consider aspects such as the role of other professionals and how they impact their delivery of dental treatment. On the other hand, IPE can be an important tool in the delivery of culturally competent dental care (Forsyth et al., 2018). Dentists must have a deep understanding of social sciences, so a dental curriculum with strong interdisciplinary modules in ethics, public health, behavioural and social sciences is important to teaching culturally sensitive care. The Universidad de La Frontera is located in a particularly vulnerable context, where, in a reduced geographical area there is a high proportion of indigenous population, poverty, rural population, and older adults, all of them with a high burden of oral diseases and chronic conditions. IPE is present in the curriculum in a diverse set of modules ranging from social sciences and public health to the integrated clinics and the internship programme as it was considered a relevant aspect of dental education in the local context. The innovated curriculum of the dental course at Universidad de La Frontera has been able to implement IPE in its curriculum and gives it an important role in the education of dentists to successfully practice the dental profession. 
ARAVENA, R. Y.; HUANQUILEF, A. M.; ARELLANO, V. M.; NUÑEZ, C. J. \& FUENTES, F. R. Un reporte del enfoque de educación interdisciplinaria en el plan de estudios de la carrera de odontología de la universidad de La Frontera. Int. J. Odontostomat., 15(1):300-305, 2021.

RESUMEN : La educación interdisciplinaria ha sido ampliamente reconocida como fundamental en la educación de nuevas generaciones de odontólogos capaces de unirse exitosamente a los sectores público y privado de salud y de otorgar tratamiento odontológico a pacientes con condiciones complejas en un sistema de salud complejo. Este artículo presenta el curriculum innovado de la carrera de odontología de la Universidad de La Frontera, describiendo sus componentes de educación interdisciplinaria (EID). Para la de EID en el plan de estudios se usaron una serie de documentos institucionales. La política de formación profesional da un marco en el cual EID es implementado en los planes de estudio de pregrado. Seis de ocho componentes del plan de estudios de la carrera de odontología incluyen EID en sus metodologías educativas: "Unidades de integración", "Cultura, hombre y sociedad", "Prevención", "Proyecciones profesionales", "Clínicas Integrales" y "Prácticas Profesionales. EID está presente a lo largo de toda la carrera de odontología del primer al último año y toma diferentes formas de acuerdo a cada componente. EID es una de las metodologías usadas para lograr los objetivos de aprendizaje establecidos en el plan de estudios. Cumplir con todas las asignaturas del plan lleva al desarrollo de habilidades genéricas y profesionales que permiten a los estudiantes obtener su título profesional.

PALABRAS CLAVE: Educación dental, relaciones interprofesionales, educación profesional, Escuelas de Odontología.

\section{REFERENCES}

Centre for the Advancement of Interprofessional Education (CAIPE). Homepage, 2017. Available from: https://www.caipe.org/

Coleman, A. J.; Finn, G. M. \& Nattress, B. R. Interprofessional education in dentistry. Br. Dent. J., 225(3):257-62, 2018.

Davis, J. M.; Janczukowicz, J.; Stewart, J.; Quinn, B. \& Feldman, C. A. Interprofessional education in dental education: An international perspective. Eur. J. Dent. Educ., 22:10-6, 2018.

Forsyth, C.; Irving, M.; Tennant, M.; Short, S. \& Gilroy, J. Indigenous cultural competence: A dental faculty curriculum review. Eur. J. Dent. Educ., 22(3):e419-26, 2018.

Fuentes, R.; Henriquez, J.; Matamala, F. \& Mardones, D. Ideas fundacionales, bases académicas y propuesta curricular innovada de la carrera de Odontología, Facultad de Medicina, Universidad de La Frontera Temuco, Chile. Rev. Estomatol., 6(1):32-8, 1996

Instituto Nacional de Estadística (INE). Resultados CENSO 2017 por País, Regiones y Comunas. Santiago de Chile, Instituto Nacional de Estadística, 2017. Available from: resultados.censo2017.cl/ Region?R=R09

Institute of Medicine. Health Professions Education: A Bridge to Quality. Washington (D. C.), National Academic Press, 2003.

Kersbergen, M. J.; Creugers, N. H. J.; Hollaar, V. R. Y. \& Laurant, M. G. $\mathrm{H}$. Perceptions of interprofessional collaboration in education of dentists and dental hygienists and the impact on dental practice in the Netherlands: A qualitative study. Eur. J. Dent. Educ., 24(1):14553, 2020.

Mendis, S. Global Status Report on Noncommunicable Diseases 2014. Geneva, World Health Organization, 2014. Available from: https:// apps.who.int/iris/bitstream/handle/10665/148114/ 9789241564854_eng.pdf; jsessionid=D4D380E4F062 CDE7D27955318ABF27D2?sequence=1

Subsecretaria de Redes Asistenciales. Orientaciones para la Implementación del Modelo de Atención Integral de Salud Familiar y Comunitaria. Santiago de Chile, Ministerio de Salud, Gobierno de Chile, 2013. Available from: https://www.minsal.cl/portal/url/item/ e7b24eef3e5cb5d1e0400101650128e9.pdf

Nafea, E. T. \& Dennick, R. Clinical reasoning skills in final-year dental students: A qualitative cross-curricula comparison. Eur. J. Dent. Educ., 22(2):101-8, 2018.

Palatta, A.; Cook, B. J.; Anderson, A. \& Valachovic, R. W. 20 years beyond the crossroads: the path to interprofessional education at U.S. dental schools. J. Dent. Educ., 79(8):982-96, 2015.

Ramaswamy, V.; Karimbux, N.; Dragan, I.; Mehta, N. \& Danciu, T. The Status of Interdisciplinary Education in Advanced Education Programs at U.S. Dental Schools. J. Dent. Educ., 82(11):1213-9, 2018.

Serra, J. \& Carrasco, M. Reflexiones sobre la Interdisciplinariedad y la Participación Social a partir de Una Experiencia Universitaria sobre Salud Comunitaria y Desarrollo Local en la Región de La Araucanía (2009). En: Ministerio de Salud. Participación Social en Salud: Reflexiones para la Acción desde Chile. Santiago de Chile, Ministerio de Salud, Subsecretaria de Redes Asistenciales, 2009. pp.277-97.

Universidad de La Frontera. Informe de Autoevaluación 2017 Carrera de Odontología. Temuco, Facultad de Odontología, Universidad de La Frontera, 2017.

Universidad de La Frontera. Reporte de gestión de decanato Facultad de Odontología 2018-2019. Temuco, Facultad de Odontología, Universidad de La Frontera, 2019.

Universidad de La Frontera. Diccionario de Competencias genéricas. Temuco, Vicerrectoría Académica, Universidad de La Frontera, 2018. Available from: http://competenciasgenericas.ufro.cl/ index.php/diccionario-de-competencias-genericas/

Universidad de La Frontera. Política Institucional de Formación Profesional. Temuco, Universidad de La Frontera, 2007. Available from: http://pregrado.ufro.cl/images/docs/Politica-formacion-profesionalufro.pdf

Wang, Z.; Feng, F.; Gao, S. \& Yang, J. A Systematic Meta-Analysis of the Effect of interprofessional education on health professions students' attitudes. J. Dent. Educ., 83(12):1361-9, 2019.

Weintraub, J. A.; Quinonez, R. B.; Friga, P. N.; Kowlowitz, V. \& Ciarrocca, K. Development of a Dental School Strategic Plan to Inform Interprofessional Education. J. Dent. Educ., 83(12):1411-9, 2019.

Wenger, E. Communities of Practice: Learning, Meaning and Identity. Cambridge, Cambridge University Press, 1998.

World Health Organization. Framework for Action on Interprofessional Education \& Collaborative Practice. Geneva, World Health Organization, 2010.

Dirección para correspondencia:

Ramón Fuentes Fernández

Departamento de Odontología Integral Adultos.

Facultad de Odontología

Universidad de La Frontera

Avda. Francisco Salazar 1145

Temuco - CHILE

Email: ramon.fuentes@ufrontera.cl 